\title{
Аналіз існуючих підходів для оцінки ефективності в предметній галузі авіаційного пошуку та рятування
}

\author{
С.М. Чумаченко ${ }^{1}$, В.В. Барбашин ${ }^{2}$, А.І. Маринін ${ }^{1}$, А.О. Мошенський ${ }^{1}$, І.В. Струнін ${ }^{1}$ \\ 1 Національний університет харчових технологій (м. Київ, Україна) \\ 2 Харківський національний університет міського господарства імені О.М. Бекетова \\ (м. Харків, Україна) e-mail: ${ }^{1}$ sergiy23.chumachenko@gmail.com
}

\begin{abstract}
Авіаційний пошук і рятування розглядається як комплекс заходів, спрямованих на виявлення повітряних суден, які зазнали або зазнають лиха, та надання своєчасної допомоги потерпілим внаслідок авіаційної події а також може розглядатися як складна організаційно-технічна система. Основними ознаками такої системи є ситуативність конфігурації та регламентованість функціонування. В умовах сучасності актуальною є проблема підвищення ефективності проведення авіаційного пошуку і рятування. Саме тому полягає необхідність у розробці системи критеріїв і показників оцінки ефективності САПіР при виконанні пошуку і рятування.

При розгляді САПіР з точки зору системного підходу, то за існуючою класифікацією її можна віднести до складних ситуативних організаційно-технічних систем.

Процеси авіаційного пошуку і рятування в складній організаційно-технічній системі здійснюється за належної взаємодії трьох визначальних його факторів: персоналу системи, засобів авіаційного пошуку і рятування та необхідних ресурсів. Використовуючи наявні засоби авіаційного пошуку і рятування, персонал системи здійснює діяльність із забезпечення послуг чергування в системі САПІР та здійснення авіаційного пошуку і рятування.

Ефективність, як категорія, стала широковживаним загальнонауковим поняттям, розширення змісту якого мало на меті відобразити співвідношення різних аспектів різноманітних видів діяльності, базою якого виступає результат діяльності. Об'єктивною оцінкою ефективності системи авіаційного пошуку і рятування буде значення відношення рівня системного «ефекту» $\mathrm{i}$ «витрат» ресурсного потенціалу системи, якими цей ефект досягнутий. Підвищення інтегральної ефективності використання ресурсного потенціалу системи при заданій технології інтенсифікації підвищує функціональний (системний) чи відповідний до нього економічний ефект в середньому на 10-30\%. Основним інструментом інтенсифікації виступає «оптимальне управління» системою авіаційного пошуку і рятування, що максимізує ії̈ ефективність.
\end{abstract}

Ключові слова: авіаційний пошук і рятування, системи авіаційного пошуку і рятування, САПіР, безпека польотів, ефективність

Постановка проблеми дослідження. Відповідно до Повітряного кодексу України від 19 травня 2011 року № 3393-VI [1, ст. 1. пп. 4, 10] авіаційний пошук і рятування розглядається як комплекс заходів, спрямованих на виявлення повітряних суден, які зазнали або зазнають лиха, та надання своєчасної допомоги потерпілим внаслідок авіаційної події, тобто - як процес - сукупність ряду послідовних дій, спрямованих на досягнення певного результату.

Разом 3 тим, авіаційний пошук і рятування може розглядатися як складна організаційно-технічна система, а саме, як сукупність елементів (органів управління, сил та засобів), об'єднаних повноваженнями та завданнями щодо реалізації комплексу відповідних заходів з авіаційного пошуку і рятування. До важливих ознак такої системи відносяться:

- ситуативність конфрігурації, тобто, залежність складу її елементів від змісту авіаційної події, місця та умов ії̈ виникнення;

- регламентованість функціонування відповідно до керівних документів.

Крім того, відповідно до п.2 статті 113 Повітряного кодексу України авіаційний пошук і рятування в Україні здійснюється в межах Єдиної державної системи цивільного захисту населення і територій, Єдиної системи проведення 
авіаційних робіт з пошуку і рятування, Національної системи пошуку і рятування на морі в порядку, встановленому спеціально уповноваженим центральним органом виконавчої влади з питань цивільного захисту [1], тобто авіаційний пошук і рятування, залежно від конкретної ситуації, є складовою Єдиної системи цивільного захисту, Єдиної системи проведення авіаційних робіт з пошуку і рятування або Національної системі пошуку та рятування на морі (див. рис. 1).

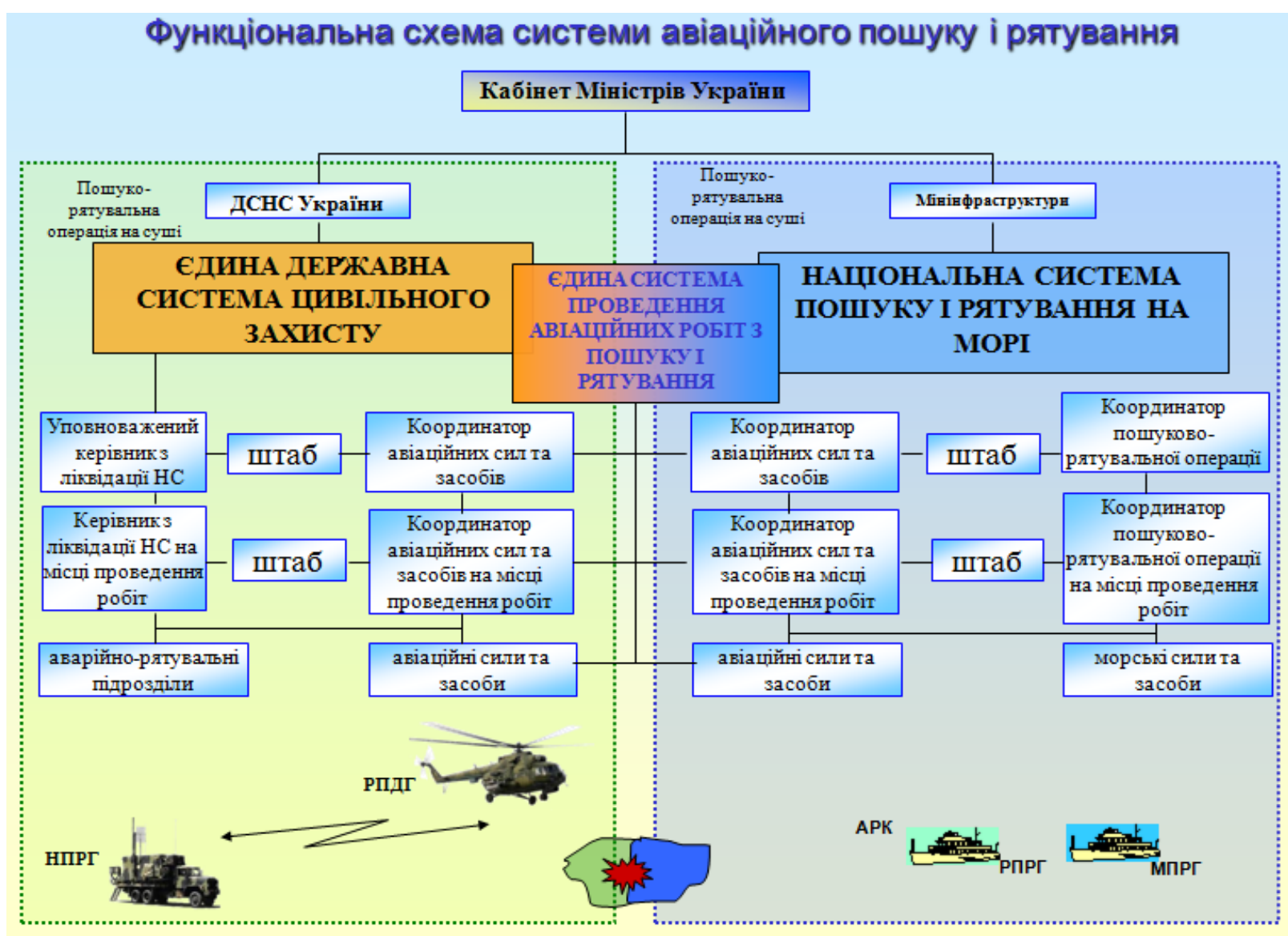

Рис. 1. Функціональна схема системи авіаційного пошуку і рятування

Об'єктом дослідження є авіаційний пошук і рятування як складна організаційно-технічна система або процес.

Предметом дослідження виступає ефективність авіаційного пошуку та рятування, розгляд якої, як категорії відносно об'єкту дослідження потребує вивчення.

Необхідною умовою діяльності як цивільної так і державної авіації (ЦА і ДА) є забезпечення безпеки польотів (БП). Аналіз статистичних даних по БП за останнє десятиліття показує, що абсолютна кількість авіаційних подій (АП) не знижується, при цьому спостерігається збільшення кількості загиблих і травмованих. Вивчення показників виживання і рятування людей в АП дає підставу зробити висновок, що кількість постраждалих і тяжкість травмування в більшості випадків можна було б зменшити шляхом підвищення ефективності системи авіаційного пошуку і рятування (САПіР). Якщо провести декомпозицію
САПіР на дві підсистеми то можна виділити умовно підсистему пошуку ПС і підсистему проведення аварійно-рятувальних робіт, що керуються підсистемою управління пошуково-рятувальними роботами (рис.2).

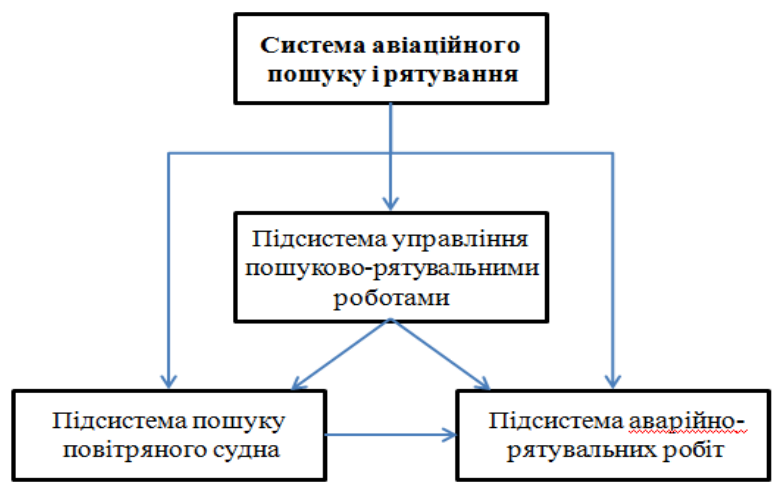

Рис. 2. Узагальнена декомпозиція системи авіаційного пошуку і рятування 
Аналіз публікацій в цій галузі. Зміст та суть ефективності в теоретичних роботах представляють як міру успішності людської діяльності, результати якої визначаються конкретними цільовими завданнями. У практичній діяльності проектувальникам нової техніки доводиться стикатися з великою кількістю різноманітних завдань i, мабуть, такою ж кількістю різноманітних підходів до оцінки ефеективності. Описати весь арсенал прикладних методик практично неможливо. Тому тут піде мова про відомості методологічного характеру, які слід розглядати як відправні положення, корисні при розробці окремих методик.

Загальний підхід до визначення ефективності, можна сказати, лежить на поверхні. Термін «ефрективність», як вказується у всіх енциклопедичних довідниках, $€$ похідним від латинського слова effektus, що в перекладі означає результат, наслідок яких-небудь причин. Ефективний відтак, той, що дає ефект. Звідси ефективність властивість системи, що приводить до потрібних результатів. Ця термінологічна характеристика відображає разом 3 тим і смисловий зміст ефективності як категорії, що виражає властивість систем у формі «мета-результат».

Слід підкреслити, що в інженерній практиці навіть саме ґрунтовне визначення суті ефрективності не $є$ вичерпною характеристикою цього поняття. Потрібне обов'язкове доповнення у вигляді вимірювального механізму, що представляє собою деяку систему показників та правил їх застосування. Така сукупність показників повинна всебічно відображати вирішувану проектну задачу. Щоб врахувати невизначеність, пов'язану 3 багатоваріантністю процесу проектування i, відповідно, багатозначністю результативності створюваної / вдосконаленої САПіР, виникає потреба двосторонньої оцінки ефективності.

Перша сторона полягає в дослідженні цільового аспекту ефективності і пов'язана з визначенням того, які властивості (параметри) відображають поставлену мету і які їх значення (нормативи) ми хочемо отримати. Відповідну характеристику співставлення «мета - кінцевий результат» зазвичай називають цільовою ефективністю. Цільова ефрективність- це кількісна характеристика кінцевого результату її функціонування і розвитку протягом обумовленого періоду порівняно з цільовим нормативом і витратою ресурсів при заданих характеристиках стану системи і впливу зовнішнього середовища, а також при заданому векторі управління. Таке трактування ефрективності, на нашу думку, досить повно відображає наведене вище визначення суті ефективності.

У відповідності 3 визначенням показник цільової ефективності системи представляється у вигляді[3]:

$$
W=W\left(Y_{\mathrm{K}}, Y_{\mathrm{H}}, U_{\mathrm{K}}, U_{\mathrm{H}}\right),
$$

де $Y_{\text {к }}$ - можливий або фактично досягнутий корисний ефрект (кінцевий результат) функціонування і розвитку системи; $Y_{\text {н }}$ - необхідний (відповідно до Т3) цільовий кінцевий результат функціонування і розвитку системи; $U_{\text {к }}$ - фактичні витрати праці на отримання $Y_{\mathrm{K}} ; U_{\mathrm{H}}-$ мінімально необхідні витрати праці на отримання $Y_{\mathrm{H}}$.

Показник ефективності у фрормі (1) може розглядатися одночасно і як критерій ефрективності. У літературі нерідко терміни «критерій» і «показник» використовуються як синоніми. Однак таке ототожнення не у всіх випадках допустимо. Критерій обов'язково $є$ основною ознакою системи, за яким визначається ступінь досягнення поставленої мети або виділяється найбільш кращий варіант. У відповідності з цим критерій ефективності можна визначити як математичне відношення, що відображає ступінь відповідності показника ефективності встановленому нормативу. У цьому сенсі критерій ефрективності може трактуватися як показник, що відображає ступінь відповідності фактичного або можливого рівня ефективності системи нормативному значенню. Зауважимо, що кінцевий результат функціонування технічних систем може відображатися цілим рядом характеристик: показники власне ефекту, надійності та ін. Вимірники витрачених ресурсів також багатомірні. Тому в ряді випадків доцільно мати кілька критеріїв та показників ефективності. Інтегральний критерій оцінки ефективності САПіР буде розписаний у наступному підрозділі.

Стосовно до завдань аналізу ефективності чітко проглядаються два підходи при фоомуванні критеріїв і показників ефективності: економічний i технічний. При економічному підході всі складові (1) зазвичай представляють у вартісному вираженні. Цьому підходу відповідає економічна ефективність систем.

Згідно з визначенням П. Хейне[4], економічна ефрективність - «властивість, найбільш послідовно звеличувана економістами. Це не повинно дивувати, оскільки ефективність і економічність майже синоніми. Обидва терміни характеризують результативність використання засобів для досягнення цілей. Отримувати якомога більше з доступних нам обмежених ресурсів - ось що ми маємо на увазі під ефективністю та економічністю».

Технічний підхід відрізняється фрізичним представленням цільових завдань. Під ефективністю тут розуміють ступінь пристосованості системи до виконання поставленої мети, тобто в основі виключно цільова сторона функціонування системи.

Друга сторона оцінки ефрективності відображає ту обставину, що отримуване при проектуванні значення цільової ефективності може бути досягнуто різними шляхами, тобто за рахунок різноманітних витрат технічних ресурсів. При 
такому дослідженні, зазвичай, розглядається вся сукупність параметрів систем. Кінцевий результат (задоволення заданої потреби) при цьому пов'язується 3 розглянутої сукупністю параметрів. Цей аспект проектування можна трактувати як задачу забезпечення якості системи, оскільки за визначенням: якість об'єкту - це найбільш повна сукупність характеристик об'єкта, що відноситься до його здатності задовольняти встановлені потреби (ISO 8402). Інтегральний показник якості у порівнянні 3 оцінкою кінцевого результату за своєю суттю $є$ узагальненою характеристикою ефективності. Цю характеристику зазвичай називають проектною ефективністю. Конкретні показники технічного аспекту ефективності (цільова та проектна ефективність) розглядаються детально в [3].В наступному підрозділі визначимо такий інтегральний показник ефективності в контексті системи АПіР.

Мета статті. На сьогоднішній день досить гостро стоїть проблема підвищення ефективності проведення авіаційного пошуку і рятування,тому метою статті $є$ розробка системи критеріїв і показників оцінки ефективності САПіР при виконанні пошуку і рятування, а також загального показника для оцінки всього комплексу робіт 3 авіаційного пошуку і рятування.

Викладення основного матеріалу. Якщо розглянути САПіР з точки зору системного підходу, то за існуючою на сьогодні класифрікацією її можна віднести до складних ситуативних організаційно-технічних систем.

За результатами наукових публікацій вітчизняних та зарубіжних авторів був проведений аналіз проблематики оцінювання ефективності складних організаційно-технічних систем [5-7]. На сьогоднішній день в узагальненому вигляді оцінювання ефективності вирішується головним чином в постановочному аспекті. Особливості вирішення цієї проблеми конкретизуються для кожної предметної галузі людської діяльності.

Як зазначалося вище,ефективність - це здатність організаційно-технічної системи (технічні пристрої + система управління + група людей + людина) створювати інтегральний ефект. Стосовно до управління складною організаційнотехнічною системою ефективність $€$ мірою точності досягнення об'єктом управління очікуваного стану. Очікуваний стан досягається за допомогою параметрів та стандартів управління.

Процеси авіаційного пошуку і рятування в складній організаційно-технічній системі здійснюється за належної взаємодії трьох визначальних його факторів: персоналу системи, засобів авіаційного пошуку і рятування та забезпечуючих ресурсів (фінансові ресурси, пально-мастильні та інші витратні матеріали).
Використовуючи наявні засоби авіаційного пошуку і рятування (літальні апарати, засоби авіаційно-технічного забезпечення польотів, засоби телекомунікацій, АРМи), персонал системи здійснює діяльність із забезпечення послуг чергування в системі САПІР та здійснення авіаційного пошуку і рятування. Це означає, що, з одного боку, мають місце затрати живої та матеріалізованої праці, а з іншого, - результати діяльності системи САПІР. Останні залежать від масштабів застосування засобів САПІР, кадрового потенціалу системи САПІР, методів управління системою САПІР та рівня її автоматизації.

Ефективність САПіР - це комплексний результат використання засобів і ресурсів САПіР й персоналу системи АПіР за певний проміжок часу.

Родовою ознакою ефективності (продуктивності) САПіР може бути необхідність досягнення мети діяльності САПіР з найменшими затратами праці персоналу САПіР, ресурсів або часу. У кінцевому підсумку змістовне тлумачення ефективності (продуктивності) як економічної категорії визначається об'єктивно діючим законом економії робочого часу. Процес формування результатів та ефективності АПІР (продуктивності системи) показано на рис. 3.

Сутнісна характеристика ефективності (продуктивності складної організаційно-технічної системи) знаходить відображення в загальній методології її визначення, формалізована фрорма якої має вигляд:

$$
\underset{(\text { продуктивність) }}{\text { Ефективність }}=\frac{\text { Результат }}{\text { Ресурси(витрати) }}
$$

Важливо нагадати, що необхідні для одержання певного результату АПІР (діяльності) ресурси розподіляються на одноразові (інвестиційні) та поточні, які витрачаються (щоденні).

Ефективність АПІР (продуктивність складної організаційно-технічної системи) має поліморфність визначення й застосування для аналітичних оцінок та управлінських рішень. 3 огляду на це важливим $\epsilon$ виокремлювання за окремими ознаками (класифікація) відповідних видів ефективності (продуктивності), кожний з яких має певне практичне значення для системи (табл. 1.).

Відповідні види ефективності (діяльності) виокремлюються переважно за різноманітністю одержуваних ефектів (результатів) діяльності системи АПIP (організаційно-технічної системи) (табл. 1). У зв'язку з цим виникає необхідність навести сутнісно-змістову характеристику окремих видів ефрективності.

Аспект управління системою має найбільшу «значимість» для інтенсифікації кожного реалізуємого способу (технології) застосування системи авіаційного пошуку і рятування і, тим самим, підвищення її ефективності.
ISSN 2311-1828

http://enm.khntusg.com.ua
Інженерія природокористування, 2020, №3(17), с. 118 - 125

Engineering of nature management, 2020, \#3(17), p. 118 - 125 

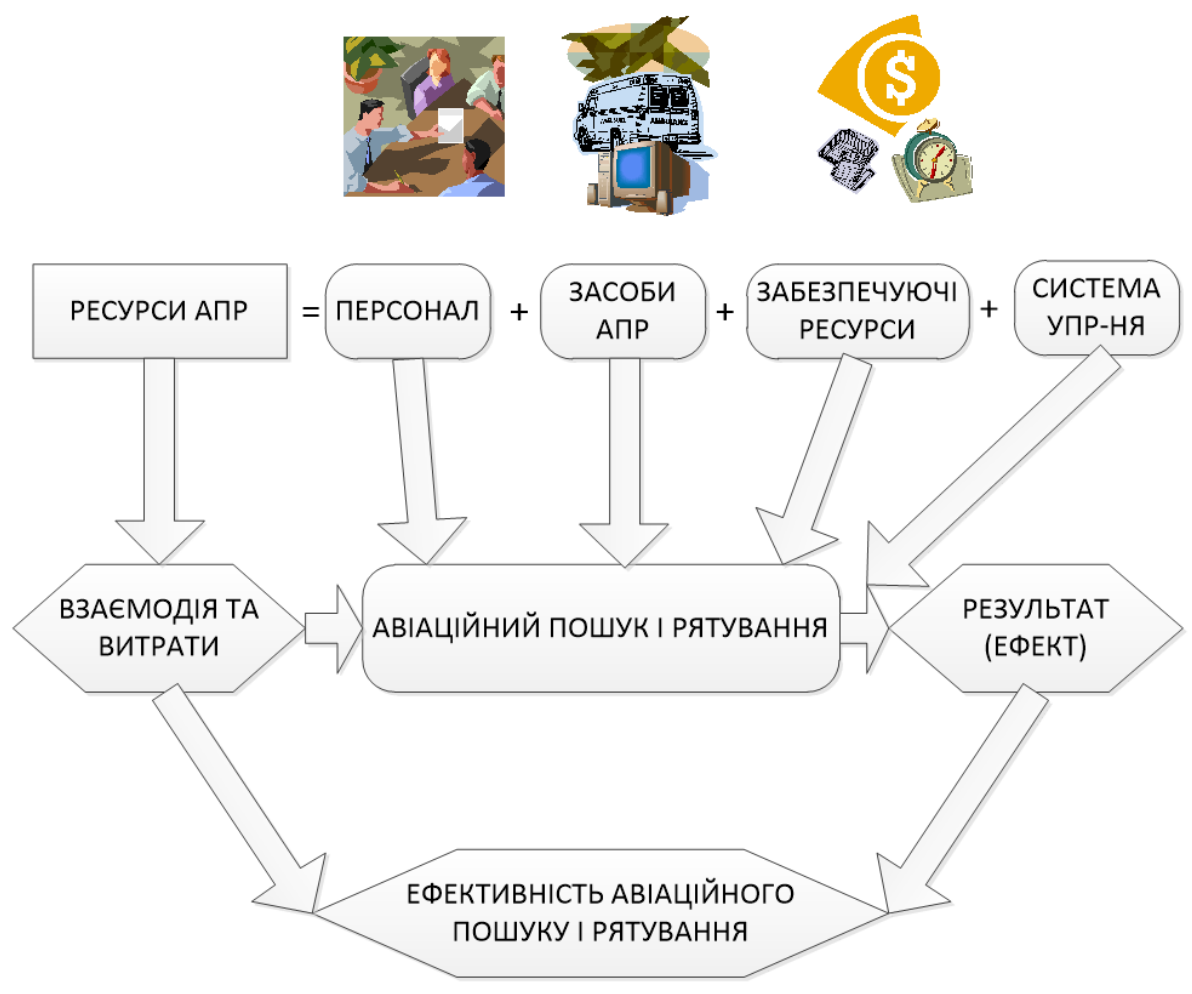

Рис. 3. Концептуальна схема формування ефективності САПіР (продуктивності складної організаційно-технічної системи)

Об'єктивною оцінкою ефрективності системи авіаційного пошуку і рятування буде значення відношення рівня системного «ефекту» WS i «витрат» ресурсного потенціалу системи RS, якими цей ефект досягнутий -

$$
E S=\left(\frac{W S}{R S}\right) .
$$

В процесі застосування системи авіаційного пошуку і рятування системний ефект «накопичується», тобто стає функцією часу -

$$
W S(t), \quad 0 \leq t \leq T S,
$$

де $T S$ - тривалість процесу застосування системи авіаційного пошуку і рятування.

Використовуючи поняття «потужності» системи як темпу зростання системного ефекту -

$$
m s(t)=\left\{\frac{d W S(t)}{d t}\right\},
$$

одержимо вираз показників продуктивності $b(t)$ «витратного» ресурсу, що перетворюється у системний ефект (паливно-мастильні матеріали, енергоносії, витратні матеріали), та продуктивності $a(t)$ «забезпечуючого» ресурсу (персонал, засоби, обладнання, інформація), що перетворює витратний ресурс -

$$
m s(t)=\left(\frac{\partial W S}{\partial r}\right) \times\left(\frac{d r}{d t}\right)=b(t) \times a(t) .
$$

\begin{tabular}{|c|c|}
\hline $\begin{array}{l}\text { Класифрікаційна } \\
\text { ознака }\end{array}$ & Ефективність \\
\hline \multirow{4}{*}{$\begin{array}{l}\text { 1. Одержаний ре- } \\
\text { зультат (наслідки) }\end{array}$} & 1. Технічна \\
\hline & 2. Економічна \\
\hline & 3. Соціальна \\
\hline & 4. Екологічна \\
\hline \multirow{2}{*}{$\begin{array}{l}\text { 2. Місце одержання } \\
\text { едректу }\end{array}$} & 1. Локальна \\
\hline & 2. Глобальна \\
\hline \multirow{2}{*}{$\begin{array}{l}\text { 3. Метод } \\
\text { розрахунку }\end{array}$} & 1. Абсолютна \\
\hline & 2. Порівняльна \\
\hline \multirow{3}{*}{$\begin{array}{l}\text { 4. Ступінь збіль- } \\
\text { шення ефректу }\end{array}$} & 1. Первинна \\
\hline & 2. Мультиплікаційна \\
\hline & 3. Синергічна \\
\hline \multirow{3}{*}{$\begin{array}{l}\text { 5. Структура } \\
\text { організації }\end{array}$} & 1. Робочого місця \\
\hline & 2. Окремого підрозділу системи \\
\hline & 3. Системи в цілому \\
\hline \multirow{3}{*}{$\begin{array}{l}\text { 6. Напрям іннова- } \\
\text { ційно-інвестиційної } \\
\text { діяльності }\end{array}$} & 1. Науки, техніки і технології \\
\hline & $\begin{array}{l}\text { 2. Організаційно-управлінських } \\
\text { інновацій } \\
\end{array}$ \\
\hline & $\begin{array}{l}\text { 3. Інвестиційних проектів і про- } \\
\text { грамм }\end{array}$ \\
\hline \multirow[b]{2}{*}{ 7. Характер витрат } & 1. Поточних витрат \\
\hline & $\begin{array}{l}\text { 2. Одноразових (капітальних) } \\
\text { витрат }\end{array}$ \\
\hline \multirow{3}{*}{ 8. Об’єкт оцінки } & 1. Повна (інтегральна) \\
\hline & 2. Часткова (окрема) \\
\hline & 3. Чинникова (багаточинникова) \\
\hline
\end{tabular}

Таблиця 1. Видова класифікація ефективності діяльності складної організаційно-технічної системи за окремими ознаками 
Системний ефект, що досягнутий в процесі застосування системи авіаційного пошуку і рятування, буде дорівнювати

$$
\begin{gathered}
W S(t=T S)=\int_{0}^{T S} m s(t) \cdot d t= \\
=\int_{0}^{T S} b(t) \cdot a(t) \cdot d t .
\end{gathered}
$$

Об'єм забезпечуючого ресурсу в процесі застосування системи авіаційного пошуку і рятування складе, очевидно -

$$
B S=\int_{0}^{T S} a(t) \cdot d t=\int_{0}^{T S} a\{X(t)\} \cdot d t
$$

де $X(t)$ - чисельність «одиниць» сил і засобів в ході процесу застосуваннясистеми $(0 \leq t \leq T S)$. Якщо вважати коректним припущення про те, що в ході процесу застосування $(0 \leq t \leq T S)$ середня чисельність сил XS і продуктивність «одиниці» сил а(1) практично не змінюються, то фрормула (7) спрощується -

$$
\begin{aligned}
& B S=\int_{0}^{T S}\{a(1) \cdot X S\} \cdot d t \approx \\
& \approx a(1) \cdot X S \cdot T S=A S \cdot T S .
\end{aligned}
$$

Середня «групова» продуктивність сил ізасобів буде

$$
A S=a(1) \cdot X S .
$$

Вважаючи, що завдання системи авіаційного пошуку і рятування досягається при рівності його «трудомісткості» $\mathrm{i}$ «трудовитрат» на її виконання із формули (7) одержимо фрормулу для «трудовитрат» ресурсної частини системи -

$$
R S=\left\{\frac{B S}{a(1)}\right\}=(X S \cdot T S) .
$$

Звичайно «трудомісткість» об'єму завдання та «трудовитрати» на його виконання оцінюють в «людино-годинах», тому вираз (11) повністю відповідає цій оцінці.

Таким чином, між чисельністю ресурсу XS та тривалістю акту виконання завдання пошуку i рятування TS при потрібному об'ємі і нормативній питомій продуктивності одиниці сил існує «гіперболічна» залежність -

$$
X S=\frac{R S}{T S}
$$

Використання залежності (11) дозволяє математично точно вирішити задачі «наукової організації» процесу застосування системи авіаційного пошуку і рятування, котрі відносяться до класу задач ресурсної оптимізації.

Відмітимо, що усі показники ефективності системи авіаційного пошуку і рятування, які пов'язані
3 кінцевим результатом її застосування, прямим чином (функціонально) залежать від «управління» системою. Управління, яке $\epsilon$ «цілеспрямовуючою» функцією, має етапи організаційного управління (розробка плану розподілу витратних ресурсів по завданням Y и плану-сценарію дій сил по застосуванню системи S) та оперативного управління (отримання відповідності процесу накопичення системного ефректу WS(t) планам $\mathrm{Y}, \mathrm{S})$. Тоді й ефеккивність системи авіаційного пошуку і рятування стає функцією управління системою $(\mathrm{Y}, \mathrm{S})$ при «нормативних» значеннях питомих продуктивностей витратних та забезпечуючих ресурсів -

$$
E S(Y, S)=\frac{W S(Y, S)}{R S(Y, S)}
$$

Оскільки досягнення «мети» в процесі застосування системи авіаційного пошуку і рятування пов'язане з потрібним рівнем системного ефректу -

$$
W S(Y, S) \geq W S^{\text {потр }},
$$

то максимізація ефективності по фрактору управління $(Y, S)$ досягається мінімізацією «витрат» за рахунок оптимального управління $(\mathrm{YO}, \mathrm{SO})$, тобто

$$
E S=\frac{W S\left(Y^{o}, S^{o}\right)}{R S\left(Y^{o}, S^{o}\right)} \Rightarrow \frac{W S^{\text {потр }}}{\min R S} \Rightarrow \max E S .
$$

Таким чином, загальна задача оптимального управління системою авіаційного пошуку і рятування має дві наступні інтерпретації.

Пряма задача - на множині управлінь $\{(Y, S)\}_{п р}$, кожне з котрих (Y,S) задовольняє обмеження на припустимий чисельний склад сил -

$$
X S(Y, S) \leq X S^{\text {прип, }}
$$

знайти таке (оптимальне) управління (YO,SO), котре мінімізує тривалість акта застосування системи -

$$
T S\left(Y^{O}, S^{O}\right)=\min _{\{(Y, S)\}} T S(Y, S) .
$$

При цьому в процесі застосування досягається максимальна «могутність» системи -

$$
M S\left(Y^{O}, S^{o}\right)=\frac{W S^{\text {потр }}}{\min T S}=\max M S
$$

і максимальна ефективність системи -

$$
E S\left(Y^{o}, S^{o}\right)_{\text {пр }}=\frac{W S^{\text {потр }}}{X S^{\text {прип }} \cdot \min T S}=\max E S
$$

Обернена задача - на множині управлінь

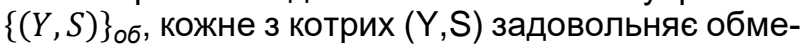
ження на припустиму тривалість процесу в процесі застосування -

$$
T S(Y, S) \leq T S^{\text {прип, }}
$$

знайти таке (оптимальне) управління (YO,SO), котре мінімізує склад сил системи - 


$$
X S\left(Y^{O}, \mathrm{~S}^{O}\right)=\min _{\{(Y, S)\}} X S(Y, S)
$$

При цьому досягається максимальна «продуктивність» сил системи авіаційного пошуку і рятування по ефректу -

$$
A S\left(Y^{O}, S^{O}\right)=\frac{W S^{\text {потр }}}{\min X S}=\max A S
$$

і максимальна ефективність системи в процесі застосування -

$$
E S\left(Y^{O}, S^{O}\right)_{\text {об }}=\frac{W S^{\text {потр }}}{T S \text { прип } \cdot \min X S}=\max E S .
$$

Висновки. Об'єктом дослідження є авіаційний пошук і рятування, який з однієї сторони, розглядається як процес - сукупність ряду послідовних дій, спрямованих на досягнення певного результату, а з іншої як, система - сукупність елементів (органів, сил та засобів), об'єднаних повноваженнями (суб'єкти) та завданнями (об'єкти) щодо реалізації комплексу відповідних заходів. Він, у залежності від конкретної ситуації, що склалася внаслідок авіаційної події, являється складовою Єдиної державної системи цивільного захисту або Національної системи пошуку і рятування на морі та має ситуативну конфігурацію.

Предметом дослідження $є$ ефективність яка, як категорія, стала широковживаним загальнонауковим поняттям, розширення змісту якого мало на меті відобразити співвідношення різних аспектів різноманітних видів діяльності (результату та витрат, результату та цілей, результату та потреб, результату та цінностей тощо), базою якого виступає результат діяльності. При цьому, об'єктивною оцінкою ефективності системи авіаційного пошуку і рятування буде значення відношення рівня системного «ефекту» і «витрат» ресурсного потенціалу системи, якими цей ефект досягнутий. Підвищення інтегральної ефективності використання ресурсного потенціалу системи при заданій технології інтенсифікації процесу перетворення ресурсного потенціалу в системний ефект підвищує функкціональний (системний) чи відповідний до нього економічний ефект в середньому на 10-30\%. Основним інструментом інтенсифрікації виступає «оптимальне управління» системою авіаційного пошуку і рятування, котре максимізує її ефективність.

Таким чином, підвищення інтегральної ефективності використання ресурсного потенціалу системи при даній технології інтенсифікації процесу перетворення ресурсного потенціалу в системний ефект підвищує функціональний (системний) чи відповідний до нього економічний ефект в середньому на 10-30\%. Основним інструментом інтенсифікації виступає «оптимальне управління» системою авіаційного пошуку і рятування, котре максимізує ії̈ ефективність.

\section{Література}

1. Повітряний кодекс України [Електронний ресурс]: за станом на 19 трав. 2011 / Кабінет Міністрів України // Законодавство України. - Режим доступу: http://zakon2.rada.gov.ua/laws/show/3393-17.

2. Національна доповідь про стан техногенної та природної безпеки в Україні у 2011 році. К.: МНС України, 2012. - 359 с.

3. Беспилотные летательные аппараты. Основы устройства и функционирования. / П.П. Афранасьев, И.С. Голубев, В.Н. Новиков, С.Г. Парафесь, М.Д. Пестов, И.К. Туркин / Под редакцией И.С. Голубева и И.К. Туркин. - Изд. Второе, переработанное и дополненное. - М.: 2008. - 656 с.

4. Хейне П. Экономический образ мышления: Пер. с англ. - М.: Новости, при участии «Cattalaxy», 1991. - 169 c.

5. Шарий В.І. Проблематика керування сферою воєнної безпеки / В.І.Шарий, А.І.Невольніченко // Наука і оборона. - 2000. - №1. - С.16-21.

6. Чумаченко С.М. Інтенсифікація ресурсного потенціалу системи воєнно-екологічної безпеки / С.М.Чумаченко, А.І. Невольніченко // Збірник наукових праць ННДЦ ОТ і ВБ України. - 2007. №3. - C. 41-47.

7. Семон Б.Й. Тезаурус фахівця як основа наукового змісту курсу навчання / Б.Й.Семон, М.П.Крюков, А.І.Невольніченко // Збірник наукових праць Національної академії оборони України. - 2004. - №54. - С. 36-42.

\section{References}

1. Povitrianyi kodeks Ukrainy [Elektronnyi resurs] : za stanom na 19 trav. 2011 / Kabinet Ministriv Ukrainy // Zakonodavstvo Ukrainy. http://zakon2.rada.gov.ua/laws/show/3393-17

2. Natsionalna dopovid pro stan tekhnohennoi ta pryrodnoi bezpeky v Ukraini u 2011 rotsi. - K.: MNS Ukrainy, 2012. - $359 \mathrm{~s}$.

3. Bespilotnye letatel'nye apparaty. Osnovy ustrojstva i funkcionirovanija. / P.P. Afanas'ev, I.S. Golubev, V.N. Novikov, S.G. Parafes', M.D. Pestov, I.K. Turkin / Pod redakciej I.S. Golubeva i I.K. Turkin. - Izd. Vtoroe, pererabotannoe i dopolnennoe. - M.: 2008. $-656 \mathrm{~s}$

4. Hejne $P$. Jekonomicheskij obraz myshlenija: Per. s angl. - M.: Novosti, pri ucha stii «Cattalaxy», 1991. - $169 \mathrm{~s}$.

5. Sharyi V.I. Problematyka keruvannia sferoiu voiennoi bezpeky / V.I. Sharyi, A.I.Nevolnichenko // Nauka i oborona. - 2000. - №1. - S.16-21.

6. Chumachenko S.M. Intensyfikatsiia resursnoho potentsialu systemy voienno-ekolohichnoi bezpeky / S.M.Chumachenko, A.I. Nevolnichenko // Zbirnyk naukovykh prats NNDTs OT i VB Ukrainy. 2007. - №3. - S. 41-47.

7. Semon B.Y. Tezaurus fakhivtsia yak osnova naukovoho zmistu kursu navchannia / B.Y.Semon, M.P.Kriukov, A.I.Nevolnichenko // Zbirnyk naukovykh prats Natsionalnoi akademii oborony Ukrainy. - 2004. - №54. - S. 36-42. 


\title{
Аннотация
}

\section{Анализ существующих подходов для оценки эффективности в предметной области авиационного поиска и спасення}

\author{
С.Н. Чумаченко, В.В. Барбашин , А.И. Марынин, А.А. Мошенский, И.В. Струнин
}

Авиационный поиск и спасание рассматривается как комплекс мероприятий, направленных на выявление воздушных судов, подвергшихся или терпящих бедствие, и оказания своевременной помощи пострадавшим в результате авиационного происшествия, а также может рассматриваться как сложная организационно-техническая система. Основными признаками такой системы является ситуативность конфигурации и регламентированность функционирования. В условиях современности актуальна проблема повышения эффективности проведения авиационного поиска и спасания. Именно поэтому заключается необходимость в разработке системы критериев и показателей оценки эффективности САПиС при выполнении поиска и спасания.

При рассмотрении САПиС с точки зрения системного подхода, то по существующей классификации ее можно отнести к сложным ситуативным организационно-техническим системам.

Процессы авиационного поиска и спасания в сложной организационно-технической системе осуществляется должного взаимодействия трех определяющих его факторов: персонала системы, средств авиационного поиска и спасания и необходимых ресурсов. Используя имеющиеся средства авиационного поиска и спасения, персонал системы осуществляет деятельность по обеспечению услуг дежурство в системе САПиС и осуществления авиационного поиска и спасания.

Эффрективность, как категория, стала широко употребляемым общенаучным понятием, расширение содержания которого имело целью отразить соотношение различных аспектов различных видов деятельности, базой которого выступает результат деятельности. Объективной оценкой эффективности системы авиационного поиска и спасения будет значение отношения уровня системного «эффекта» и «расходов» ресурсного потенциала системы, которыми этот эффект достигнут. Повышение интегральной эффективности использования ресурсного потенциала системы при заданной технологии интенсификации повышает функциональный (системный) или соответствующий ему экономический эфрфект в среднем на 10-30\%. Основным инструментом интенсификации выступает «оптимальное управление» системой авиационного поиска и спасания, что максимизирует ее эффективность.

Ключевые слова: авиационный поиск и спасание, система авиационного поиска и спасания, САПиС, безопасность полетов, эфрфективность

\section{Abstract \\ Analysis of existing approaches to assess the effectiveness in the subject area of aviation search and rescue}

\section{S.M. Chumachenko,V.V. Barbashyn , A.I. Marynin, A.O. Moshenskyi, I.V. Strunin}

Aviation search and rescue is considered as a set of measures aimed at identifying aircraft that have suffered or are in distress and providing timely assistance to victims of an aviation accident, and can also be considered as a complex organizational and technical system. The main features of such a system are situational configuration and regulation of functioning. In modern conditions, the problem of increasing the efficiency of aviation search and rescue is urgent. That is why there is a need to develop a system of criteria and indicators for assessing the effectiveness of SoEFH when performing search and rescue.

When considering SoEFH from the point of view of a systems approach, then according to the existing classification it can be attributed to complex situational organizational and technical systems.

The processes of aviation search and rescue in a complex organizational and technical system is carried out by the proper interaction of three determining factors: the personnel of the system, the means of aviation search and rescue and the necessary resources. Using the available means of aviation search and rescue, the personnel of the system carry out activities to provide watch services in the SoEFH system and the implementation of aviation search and rescue.

Efficiency, as a category, has become a widely used general scientific concept, the expansion of the content of which was intended to reflect the ratio of various aspects of various types of activity, the basis of which is the result of the activity. An objective assessment of the effectiveness of the aviation search and rescue system will be the value of the ratio of the level of the systemic "effect" and the "costs" of the resource potential of the system, which achieved this effect. Increasing the integral efficiency of using the resource potential of the system with a given intensification technology increases the functional (systemic) or corresponding economic effect by an average of $10-30 \%$. The main instrument of intensification is "optimal control" of the aviation search and rescue system, which maximizes its efficiency.

Keywords: aviation search and rescue, systems of emergency feed and handling, SoEFH, flight safety, efficiency

Бібліографічне посилання/ Bibliography citation: Harvard

Chumachenko, S. M. et al. (2020) 'Analysis of existing approaches to assess the effectiveness in the subject area of aviation search and rescue', Engineering of nature management, (3(17), pp. $118-125$.

Подано до редакції / Received: 02.09.2020

ISSN 2311-1828

http://enm.khntusg.com.ua
Інженерія природокористування, 2020, №3(17), с. 118 - 125

Engineering of nature management, 2020, \#3(17), p. 118 - 125 